\title{
The Ninth Symphony of Beethoven, Its Rich History
}

\section{Campbell Shiflett}

In 1987, an article by Susan McClary appeared in the Minnesota Composers Forum Newsletter. Titled "Getting Down Off the Beanstalk: The Presence of a Woman's Voice in Janika Vandervelde's Genesis II," the essay explored how the mechanics of tension and resolution in music could be said to reflect gendered perspectives on pleasure. Vandervelde's 1983 piano trio serves as McClary's principal illustration of this, a work she argues offers a compelling critique of a Western musical tradition according to which works struggle toward a singularly intense (and often brutal) "climax." To McClary, Genesis II not only exposes the destructive potential of this teleological norm, which she associates with the rule of sexuality by the phallus, but also suggests how the dominance of this rule within works and across history has resulted in the exclusion of other kinds of musical eroticism, including those more representative of the experiences of women.

Interleaved within McClary's commentary, however, are a number of more or less passing references to other musical works and genres-ranging from Mahler to metal to minimalism-which serve as points of comparison or contrast with Genesis II. And as responses to McClary's essay began to appear, it was one of these that would provoke readers more than any of her other musical examples, not only overshadowing Vandervelde's piece to assume a priority all its own, but helping to spark a debate that would continue for years. The work was Beethoven's Ninth Symphony, whose overwhelming sound McClary associated not with the ecstatic joy of the Schiller Ode featured in its finale, but with physical and sexual violence.

McClary's comments about the symphony, especially as they appeared, revised, in her 1991 book Feminine Endings, are well known to Anglophone musicology. They have been subject to immense scrutiny by defenders and detractors alike, inspiring an animated exchange among scholars that has achieved a similar fame. Yet as critics quoted, paraphrased, questioned, and appraised McClary's claims in their debate over how best to understand the cultural icon that is Beethoven's Ninth-and as more recent scholars have looked back on an iconic moment in the history of the discipline to reflect on the force of McClary's criticism-these writers seem on the whole to have overlooked (or 
at least underestimated) one key source, witness to both McClary's initial argument and the polemics that ensued.

Adrienne Rich's poem "The Ninth Symphony of Beethoven Understood at Last as a Sexual Message," from her 1973 collection Diving into the Wreck, was first introduced to musicology when it appeared, reprinted in its entirety, in McClary's "Beanstalk" essay. And it has lived an uneasy life within the discipline ever since. For while supporters and critics of McClary alike frequently recall the poem in responses to her essay, their engagement with Rich's verse is, on the whole, limited to reductive paraphrase or unqualified quotation, and tends to treat the poem as an accessory to McClary's prose. Rarely do these writers consider Rich's work as a text in its own right-a text whose perspective on the Ninth not only merits the same careful reading and deliberate explication as Beethoven's symphony and McClary's essay have received, but which also might serve as a point of origin for further reflections on the Ninth and on the debates that have surrounded it. That is to say, while Rich's poem has gained considerable currency within musicology, musicologists have only seldom and briefly reflected on its significance-both in terms of how its text signifies and what it means to our discipline.

Looking back on this history and reviewing how Rich's text has been put to use, we might finally acknowledge the role this long-underappreciated poem has played in our field. And by reframing this disciplinary turning point with the poem in mind, we might also consider how bringing Rich's text from the margins of musicology to the center of analysis affects how we understand its commentary on the Ninth. That we would do so in the echo of the pomp and circumstance of the $250^{\text {th }}$ anniversary of Beethoven's birth is, of course, not immaterial. But the Beethoven Year means more to this study than simply providing a convenient excuse to recall a contentious period in the history of musicology, or else an opportunity to rescue Rich's verse from obscurity in his name. The scholarship discussed below, much of it foundational to American feminist music criticism, merits close study regardless of the season. And Rich's powerful verse, though certainly less well known than Beethoven's Ninth, hardly needs a musicologist to sing its praises. Rather, if we return to these polemics and to this poem now, it is above all because we owe it to ourselves as music scholars to reflect on our field's curious attachment to Rich's work. We ought to consider the implications of our discipline's tendency to fleetingly invoke this relatively unknown text alongside one of the most famous pieces of music ever composed, and alongside one of the most infamous musicological quarrels. ${ }^{1}$ 


\section{Current Musicology}

Still, if diving into the wreck of these decades-old polemics is especially meaningful for this Beethoven Year, it is because looking more closely at Rich's poem requires us to confront the same anxieties that motivated writers to cite this text amid their reflections on that composer's legacy: anxieties over the nature and value of interpretive criticism, and over the reassessment of musical (and musicological) icons.

\section{First Appearances}

In the Composers Forum version of "Getting Down Off the Beanstalk," McClary highlights two sections of Beethoven's symphony as evoking sexual violence: The point of recapitulation in the first movement, "one of the most horrifying moments in music," in which "the carefully prepared cadence is frustrated, damming up energy which finally explodes in the throttling, murderous rage of a rapist incapable of attaining release." And the work's finale, in which the symphony "simply forces closure by bludgeoning the cadence and the piece to death" (1987, n.p.). After proposing this way of hearing the Ninth, McClary introduces Rich's poem, reprinting it in its entirety and describing it only as a "remarkably similar reading" to her own:

A man in terror of impotence

or infertility, not knowing the difference

a man trying to tell something

howling from the climacteric

music of the entirely isolated soul

yelling at Joy from the tunnel of the ego

music without the ghost

of another person in it, music

trying to tell something the man

does not want out, would keep if he could

gagged and bound and flogged with chords of Joy

where everything is silence and the

beating of a bloody fist upon

a splintered table

(Rich 1973, 43)

There are similarities between the two readings, certainly, but there are also differences. Twice mentioning "Joy", Rich seems to be invoking the final movement of Beethoven's symphony where McClary writes also of the first. Rich's references to Joy moreover suggest that she writes of the symphony's sound more abstractly than McClary, who analyzes more specific aspects of the 
music. ${ }^{2}$ The poet's description of the "beating of a bloody fist" seems aligned with McClary's "bludgeoning," though Rich's beating is threatening and destructive while McClary's is explicitly deadly.

The two authors also differ in their description of who is responsible for the violence they describe. In McClary's analysis (at least in this version of her essay), the identity of this agent is more or less indeterminate. Her personification of the symphony-whose "frustrated" music "explodes," whose "promised" cadences "are withheld," and which ultimately "forces closure" upon itself-paints an ambivalent picture of the Ninth as both perpetrator and victim of violence. And so, ultimately, it leaves unclear whether we are to understand the work's destruction as essential to the music (its intended expression), or else as the violation of the music by the same willful force that gives it life (a composerly intrusion). And yet, even as McClary's text obscures the identity of her agent, the conflict it describes seems to be an internal one, whether one hears the violence committed against the work as a product of the symphony's own rage, or else the rage of a willful composer who violates a piece of music that is ultimately his own expression.

By contrast, Rich's poem rather clearly identifies its protagonist as "a man trying to tell something," and it describes his violence in the language of external conflict. (He yells, flogs, silences.) Though now, however, it is the object of his anger that is left obscure: Here he roars at Joy, there he is confronted with the music's co-equal power "to tell something." Still later, he gags and binds not the music but what it threatens to disclose ("something the man does not want out") - this latter fact being another significant point of contrast with McClary's essay. What is more, unlike McClary's obscure actor, who appears to successfully take control of the music, Rich's man seems unable to prevent his music from revealing what he wants suppressed. His most explicit violence is, in the end, only imagined-what he "would [do] ... if he could."

These and other differences between the two texts' perspectives on the symphony might easily go unnoticed and their significance unquestioned, especially since McClary neither comments on specific lines from Rich's work nor offers any details about the poet or her work in the article. Her readers, confronted with Rich's text, are left to compare and contrast the authors' positions themselves. Still, McClary's framing of the poem would presumably encourage readings more attuned to the "remarkable similarity" of these texts than to their differences, even if the precise terms of their similarity are left unsaid. Indeed, as history proved, McClary's readers considered Rich's poem a crucial piece of evidence corroborating her claims, surely encouraged in this 


\section{Current Musicology}

belief not only by McClary's suggestion of their similarity, but also by the poem's prominence in her essay: Despite its brief appearance, the work's intrusive voice, striking imagery, and physical presence on the page draw considerable focus.

McClary included her essay on Genesis II in her 1991 monograph Feminine Endings, in which she sketches out a number of potential avenues of inquiry for a nascent feminist music criticism. In preparing the article for republication, she significantly revised her comments on the Ninth, eliminating the comparison to rape and recasting her description of its finale to focus on the inadequacy of any musical gesture to resolve such an enormous work. Despite these changes however, she again dubs Rich's reading of the Beethoven symphony in her poem "remarkably similar," a fact which suggests how broad she considers this similarity to be. From here, McClary goes on to deny that Beethoven himself is "exceptionally monstrous," proposing rather that his symphony is but one musical symptom of a socially systemic sexism. This too would suggest that her more circumspect analysis corresponds with Rich's more outspoken criticism of the Ninth only at a certain level of generality $(1991,129)$.

The remainder of McClary's commentary on Beethoven's symphony bears this out: Admitting that the Ninth itself might be interpreted as a critique of the phallic compositional customs she describes, exaggerating the drive toward climax and closure to demonstrate the violence with which these norms are enacted and enforced, McClary concludes that Beethoven's work would in this case be "every bit as devastating" as Rich's account of the symphony (ibid.). With this remarkable comparison, McClary suggests a meaningful difference between her perspective on the symphony and Rich's, which has subtle but significant implications for her revised text. Where in the Composers Forum article McClary draws on Rich's poem to lend credence to her more provocative claims, here she invokes the text as a more extreme perspective against which she can counterpose her more cautious line of inquiry. But whatever this statement might suggest about the similarity of the writers' views or about the role McClary intends Rich's poem to serve in her text, it is ultimately left for the reader to determine. For McClary again offers no commentary on the "remarkably similar" poem, leaving unclear whether its inclusion is meant to support her claims or serve as a foil to them.

In the debates that erupted over Feminine Endings-debates catalyzed by the book's suggestion that Beethoven's works are complicit in a tradition of Western misogyny-McClary's critics decried her interpretive criticism as politically motivated, chiding her for her neglect of the details of Beethoven's score and advocating for a return to the music itself as the source of 
musicological insight. In these early responses to McClary, references to Rich were slow to appear. Pieter van den Toorn, one of the first and most vocal critics of Feminine Endings, did not mention Rich or her poem in his initial response to the book (1991) or in his eventual monograph Music, Politics, and the Academy (1995). Though in a reply to van den Toorn, Ruth Solie did briefly return Adrienne Rich to the conversation surrounding McClary's work: Referencing Rich's theory of "compulsory heterosexuality" (according to which a woman's sexuality, under patriarchal rule, can only be thought in terms of her relation to a male partner), she defends McClary's book from accusations that it reduces gender to sexuality alone. ${ }^{3}$ Solie's engagement with Rich's writings here allows Rich's voice to come to the aid of McClary's scholarship more substantially than in the "Beanstalk" essay. But what is more, Solie's citation endows Rich with authority as a feminist thinker in addition to a provocative poet, acknowledging and engaging with her work in a way that was uncommon to many responses to McClary's work.

When musicologists did begin to reference the "Beethoven" poem in their responses to Feminine Endings, however, Rich's text quickly gained special significance for its relevance to McClary's argument about the Ninth-even as these commenters referenced the poem only in passing, and to divergent ends. In an overall positive review of the book, for instance, Jann Pasler quotes four lines from Rich's work to convey the "sexual message" it describes, a message she holds up as an illustration of the patriarchal traditions McClary calls into question $(1992,203)$. Pasler does not offer an interpretation of Rich's verse however; indeed, she pivots away from Rich's poem almost as soon as she has mentioned it. And yet by linking McClary and Rich in this short space she suggests that the poem be read according to McClary's commentary on the Ninth, effectively eliding the two authors' perspectives-a strange thing considering that both McClary and Pasler ostensibly cite the poem to lend credence to the arguments laid out in Feminine Endings, not the other way around.

In a more critical assessment of the book, meanwhile, Leo Treitler reproduces the complete text of the "Beethoven" poem to exemplify what he sees as a central issue undermining the strength of McClary's analysis: Troubled by her insistence on the similarity of her conception of the symphony to Rich's, Treitler rejects the notion that "a critic's reading" and "a poet's sense" of the Beethoven symphony should be considered on equal terms, finding in the authors' writings not so much a difference in view as in generic obligation. Noting that music criticism has at its basis a critic's response to music, he 


\section{Current Musicology}

suggests McClary's inconclusive and adversarial writing is principally motivated by a political project rather than by Beethoven's work - and is thus unbecoming of music criticism. Yet at the same time, Treitler seems to condone this polemical quality in Rich's poem. Even as he offers no comment on or interpretation of the text, he does acknowledge its poetry as an expression of a certain "sense" or "feeling." What is more, in reproducing the entire poem he makes considerable space for Rich's text in his essay. ${ }^{4}$

In differentiating Rich's poem from the ideals of academic writing to which McClary's prose aspires, Treitler suggests that the two texts have different responsibilities to their objects of study: The poet's writing can afford more imaginative treatment of its material, while the scholar's must keep close to fact in its research and maintain fidelity in its reportage. His concern with the nature of the critic's interpretive labor-a concern he broaches amid a critique of McClary's interpretation of the Ninth, but which surely inspired McClary herself to propose her unorthodox reading of the symphony in the first place-thus reveals a related concern over how to read Feminine Endings: whether as creative writing, as academic scholarship, or as something else. (Indeed, Treitler goes on from here to describe McClary's work somewhat contemptuously as a speechact that aims at a purely autonomous criticism, free from all objects of critique.) His concern, if couched somewhat insensitively, was prescient nonetheless. The question of how best to read McClary's analysis of the Ninth became crucial in the years to follow, as music scholars revisited Feminine Endings with hindsight after the debates it inspired had cooled. Still, the same care was only inconsistently extended to the reading of Rich's poem, which remained a fixture in these discussions.

\section{Continuing Reflections}

As feminist musicology developed through the 1990s, its advocates continued to resist calls from critics in the vein of Treitler and van den Toorn for a return to the music itself, insisting on the importance of music's social implications to the study of musicology. In a review of the volume in which Treitler's essay appears, Mary Ann Smart offers a concise explanation for why: Those who demand that music criticism ought to proceed principally from the study of works fail to recognize that there can be no straightforward return to a music that is unsafe, its critics having marked it as representative of sexual violence (1994, 546-47).

But despite feminist critics' concern for music's social and political implications, close analysis of Rich's poem as an element of the social network 
surrounding Beethoven's Ninth was slow to follow. For example, Smart's defense of feminist hermeneutics against Treitler's critique begins with a brief invocation of Rich's poem, which she suggests (ostensibly agreeing with Treitler) demands a different kind of interpretive work from its reader than does McClary's "Beanstalk" essay. In the end however, Smart (again like Treitler) does not offer any explicit commentary on the poem, and she seems somewhat suspicious of poetry's place in music criticism. ${ }^{5}$ Her rather summary treatment of Rich's work is not unusual, but here it speaks to a curious fact about the role of the poem in discussions of McClary's criticism-that as feminist writers not only continued to reflect on the significance of the Ninth, but now also began to consider how best to understand McClary's commentary on Beethoven's work, these writers on the whole did not interpret Rich's poem with the same careful attention.

In a 1997 article, Tia DeNora mentions Rich's illustration of the Ninth's "sexual messages" in order to compare them with the "phallocentric" compositional devices McClary describes. Both she casts in terms of metaphor, with Rich and McClary calling upon the symphony to serve as an analogue for something non-musical $(1997,55)$. But DeNora's fleeting suggestion of the similarity of Rich's and McClary's texts stops short of recognizing a crucial difference between how the two writers' metaphors affect how their works are read. Rich's text bears its metaphors more overtly, its title openly acknowledging its central conceit and its framing as a poem encouraging readers to consider its language as figurative. While McClary's metaphors often read as statements of fact, keeping its metaphors relatively concealed (a common feature of academic writing, which privileges such directness), and offering no overt signal for the reader to understand them as figurative language. This distinction suggests a reason for the differences in the reception of Rich's and McClary's texts. The former, laying bare its metaphors, does not attract suspicion and, safely aestheticized, maintains a plausible deniability alongside its creative license. The latter, deploying its metaphors more covertly, attracts the scrutiny of scholars like Treitler, who pick apart its language and view its creative engagement with critical concerns as interpretive overreach. That DeNora herself glosses over the distinction might lend further credence to this counterintuitive notion: Rich's figurative language is apparently so blatant that critics feel no need to elaborate upon her text's implications.

Suzanne Cusick briefly mentions McClary's invocation of Rich's poem to similar effect in a footnote to her 1999 survey of the impact of Feminine Endings on musicology. Emphasizing that McClary's book ought not be taken as emblematic of feminist music criticism more generally, Cusick advocates that 


\section{Current Musicology}

Feminine Endings ought to be considered within a larger "feminist intellectual context," and she decries the constant misquotation and misrepresentation of McClary's work by critics who fail to contextualize the claims of her book. ${ }^{6}$ And yet she proposes at the same time that by deferring to the poem McClary uses Rich's text to suggestively conclude her account of the Ninth:

McClary surely suggests a narrative of violent sexual release in her remarks about the symphony, but she lets Adrienne Rich's poem [...] provide the last eloquent words of her reading. Rich's poem need not be taken as describing a rape either, but rather as the explosive frustration of "A man in terror of impotence / or infertility, not knowing the difference / a man trying to tell something / ... yelling at Joy from the tunnel of the ego." (ibid., 488n.30)

Cusick's account leaves unclear what motivates this aspect of McClary's rhetoric. Perhaps it is meant to be intentionally manipulative, the author exploiting the poem for what it suggests while she avoids the topic herself. Or perhaps, more charitably, it is an admission of the poem's complexities, the author's lack of comment a cue to the reader to examine the poem from multiple perspectives. In either case, however, Cusick's proposition that Rich's poem is valuable to McClary's writing because of its power of suggestion would seem somewhat dissonant with her larger point that understanding McClary's essay properly requires its situation within a particular intellectual context. That Cusick herself has little to say about Rich's poem-appropriating its opening lines just as McClary did to suggestively conclude her own entry in the history of this poem's reception-also seems counterintuitive. Her isolated quotation of the poem, recalling its use by earlier writers, involves no attempt to situate Rich's poem within a particular discursive context. In doing so, her footnote unexpectedly suggests that feminist writers, citing the text without acknowledging what or how it signifies, risk turning it into something of an aesthetic object, a text which speaks for itself-precisely the kind of criticism they were reacting against.

As the debate surrounding Feminine Endings cooled in the early years of the twenty-first century and took on a larger disciplinary and historical significance, scholars began to invoke Rich's poem in their accounts of the debates surrounding McClary's reading of the Ninth. Perhaps understandably, these authors cite and paraphrase Rich's poem still more cavalierly than earlier critics. David Levy mentions Rich's poem in passing in his account of the Ninth, identifying the "man" of the text simply as Beethoven himself, while that same year Lewis Lockwood quotes from Rich's poem in a book on Beethoven, attributing it to "a feminist poet." Elsewhere, Richard Taruskin quotes a passage about Rich and McClary from an uncredited publication he was asked to review 
that describes Rich as having criticized Beethoven's "controlling power" (2009, 78). These three authors make little space for considered interpretations of the poem, and demonstrate the lowest possible level of involvement with Rich's text without omitting it entirely.

Other critics, however, did engage Rich's text in more deliberate and systematic ways. In a 2004 essay, Robert Fink takes up the poem at some length alongside McClary's essay: He considers how the two texts can be read both for what they say and for what they imply, finding for instance that Rich and McClary each use "imagery and tone" to "conjure up the specter of rape" without mentioning it explicitly $(2004,142)$. He offers a rare comparison of the structures of the poem and the symphony, each of which shares a trochaic stress pattern at its close. And twice he suggests the importance of Rich's poem to musicology after its "introduction" by McClary. But here too there are troubling aspects to Fink's treatment of the poem. For one, though he includes the complete text of Rich's work, he divides it between two epigraphs at either end of his essay, making it more difficult to read on its own. Then, when Fink (after dropping several suggestive quotations) finally names the poem in the body of his text, describing its titular "Message" as "profoundly dystopic and disturbing," he proceeds to generalize Rich's characterization of the Ninth to other possible hearings of the work-relating the work's violence, for example, to the oppressive political climate in Austria during the decade of the work's composition (ibid., 143). And finally, just after claiming that the identification of Beethoven with a rapist is "not as clear-cut as simplifying accounts of McClary might imply," Fink resolves that the composer is in fact a rapist, who violates his own work by forcing his "crude solipsistic tonal desires" on what had been a "complex formal dialectic." Writing that Beethoven "smashed his own Ode to Joy into pieces" to conceal his "formal impotence," he concludes, suddenly and simply, that "Adrienne Rich was right" (ibid., 147).

These points of dissonance in Fink's essay recall his initial comments on the slippage between what Rich's text makes explicit and what it suggests to the reader. This peril of interpretation, long familiar from analyses of the Ninth and more recently so from commentaries on Feminine Endings, can here begin to be felt in Fink's struggle to read and represent the poem. Fink even seems to recognize this connection himself when he links the overwhelming noise of the Symphony's close and the unease of McClary's figurative description of that passage to the "brutal trochaic pentameter" of the closing lines of Rich's work. In this way, his account suggests something profound about Rich's poem: that, as with Beethoven's Ninth and McClary's account of the symphony, any 


\section{Current Musicology}

determination of its meaning likewise stems from a contingent act of interpretation shaped simultaneously by what its text affords and by what a reader is able to detect. Fink's demonstration of this contingency in his writing would suggest too that readers of Rich's poem who, having determined its significance for themselves, wish to represent this significance to others must be attentive to this duality of interpretation as well: both to convey the complexity of the text they analyze and to acknowledge their role in transmitting the text to their audience.

Still more recently, Michael Broyles has taken up Rich's poem in his book Beethoven in America, where he offers a close reading of the text, a rarity among musicologists' invocations of Rich (2011, 139ff). His rather idiosyncratic take on the poem (in which he concludes, rather uniquely among Rich's commenters, that Beethoven himself is the one gagged, bound, and flogged-and by his own music!) testifies both to the variety of interpretations Rich's text can inspire and to the necessity of representing this interpretive work with care, since neither the meaning of Rich's poem nor the critic's understanding of it can be taken for granted. Along with this, Broyles includes a brief biographical sketch of the poet and an overview of its appearances in musicology. He explains that for many years "The Ninth Symphony" was relatively unknown among Rich's poems, but that it had developed a certain prominence due to its appearance in McClary's "Beanstalk" essay and its reappearance in the writings it inspired. He also notes the parallel imagery between Rich's poem and McClary's essay, finding that both authors hear the symphony's sublimity as violence rather than as energizing power (although he admits that Rich's poem is broader in its scope, addressing the Ninth as a whole, while McClary considers particular musical moments).

Especially noteworthy in Broyles's account however is its unique concern with the context of the poem's composition. The author notes, for example, that the work was written one year after the release of Stanley Kubrick's film adaptation of A Clockwork Orange, in which the Ninth's violent implications feature prominently. After corresponding with Rich, Broyles relays that while she claimed to have seen the film around the time of writing "The Ninth Symphony" (but not to have read the novel by Anthony Burgess upon which it was based), she was unaware of any conscious influence. Rather, she wrote the poem after hearing the symphony on the radio and rediscovering its "certain kind of male anguish and emotional isolation" (ibid., 141). Rich admitted to Broyles however that she never intended her poem to be about Beethoven himself. $^{8}$ 
Both Broyles and Fink begin to parse Rich's poem, to unpack its claims, and to consider the contexts in which it has been involved. Yet their accountswhile certainly a great improvement from anonymous references to the "feminist poet"-only begin to treat Rich's verse as a source of musicological insight. Neither author presents a systematic reading of her text that reflects the difficulty of its interpretation, and neither considers the poem's significance to musicology beyond the fact of its appearance in McClary's writings and in those her text inspired. And so their analyses, though encouraging, do not unsettle a decadeslong tradition of musicologists affirming the immense significance of Rich's poem while only glancingly suggesting how it signifies: from McClary's ambivalent use of the "remarkably similar" work's extreme perspective as a foil in Feminine Endings, to Treitler's tacit approval of the poem as an aesthetic object, to Cusick's appropriation of its suggestive language, to its casual inclusion in surveys of feminist music criticism, in studies of Beethoven's Ninth, and in contexts still further removed from those in which it first appeared in musicology. ${ }^{9}$

And it is this trend, more than any one critic's fleeting invocation of the poem, that is troubling. For it perpetuates a certain image of Rich's versewhether treated as a mere mirror of McClary's essay, an aesthetic object, a provocative quote, or a mere music-historical curiosity-as a text whose interpretation need not feature in any scholarly inquiry, its meaning able to be either recovered at a glance, or gleaned from the contexts in which it is cited, or else simply thought through by readers in their own time. And this image is inconsistent not only with the concerns that motivated the poem's inclusion in McClary's analysis of the Ninth and sustained the discourse that grew up around her essay, but also with the lessons that musicology has learned from that exchange.

\section{Toward an Understanding (At Last?)}

This treatment of the poem is not limited to its appearances within music criticism either. When the work is mentioned at all in studies of Rich's poetry, it tends to feature only in passing. Andrew Hudgins's only comment on the poem in his close reading of Diving into the Wreck is that it criticizes masculine solipsism "because of a fear of impotence or infertility" $(1981,59)$. Other writers are less kind: Janice Markey, amid a familiar array of quotes and paraphrases, describes "The Ninth Symphony" as "unworthy of a poet with such high ideals and standards," "dishonest," and "obviously unfair" to Beethoven for not 


\section{Current Musicology}

mentioning his struggle with deafness and "the great emotional impact of his music" (1985, 191). Claire Keyes likewise calls Rich an "ideologue" and only mentions "The Ninth Symphony" in her study of Rich's poetry as an example of the "absurdity" of her extremism $(1986,135)$. Another critic brings up the poem only to mention that its title would alarm a censor (Lemardeley-Cunci 1990, 14).

Yet where these authors find madness, another strand of criticism finds method: Paula Bennett writes of Rich's confrontational work as a "necessary first step" toward a feminist poetics $(1986,218)$. While Alice Templeton suggests that what others might label Rich's "aesthetic failures" are self-authorizing attempts at writing from a feminist perspective, referencing "The Ninth Symphony" in particular as a "test" of the "validity of [Rich's] feminist thinking" that attempts to translate personal experiences into shared stories $(1994,34)$. Jean Kreiling approaches a similar conclusion about Rich's experimental style in her analysis of the poem, which, though brief, represents perhaps the most encouraging example of a critic's engagement with the text. Her close reading of Rich's verse alongside other poetic responses to Beethoven's symphony (contextualized with reference to McClary's and Fink's writings) demonstrates how the poem's unsettling subject matter, strange construction, and passionate activism make it difficult to interpret the titular "Message" it is supposed to describe. She notes for example how the absurd length of the title and the poet's pun on the word "chords" add an unsettlingly playful dimension to an otherwise "nightmarish" work. And she comments at length on the poem's baffling syntax and lack of punctuation, which she finds contribute an indistinct emotional energy to Rich's verse $(2012,59)$.

It is worth dwelling on this notion that the poem's confusing syntax, semantic misalignments, and affecting language encumber its interpretation, for Kreiling's claim can begin to suggest a reason for why decades of critics have treated the work the way they have. Prompting readers to discern a "Message" from its grammatical ambiguity, narrative inconsistency, and overpowering passion, the obscurity of Rich's verse-what one might call its textual noisewould serve as the fertile soil from which a reader's interpretation of the poem might arise. Yet, at the same time, this textual noise would guarantee that any such understanding necessarily be incomplete, as it forecloses upon the work's other possible interpretations. This could explain the prevalence of direct quotation in musicologists' nods to Rich's verse, a strategy that would pretend to avoid this double bind of interpretation. It could also explain why critics, quoting from Rich's suggestive poem, seem so often to frame her text either as a provocation for their own readers' reflections (focusing on the promise and 
potential of its noise), or as a confusing polemic, unruly and unfair (focusing on its perilous imprecision).

And yet neither of these perspectives on the poem alone entirely captures the richness of its "noise." Calling the work unfair for demanding so much work of its reader certainly does not acknowledge the intricacy of its text. But neither does yielding to the text's suggestiveness, presenting it with minimal commentary so as to encourage a reader's own deliberations on its significance, and a critic who does so not only glosses over the details of the text's semantic potential, but also falsely denies their role in representing the text to their audience in all its difficulty. (reliance on direct quotation obscures this fact in both of these cases). Instead, an account of the poem ought to balance elements from both of these perspectives on Rich's text, exploring its manifold semantic potential to explain how its textual noise both encourages and hinders interpretation-as any decision on its meaning means the exclusion of other possible meanings. And yet, while critics must have felt this difficulty in their encounters with the text, it remained a largely unspoken fact. Its effect on their analyses and on the larger role of Rich's poem within musicology has never quite been a focus of their work-a strange thing, considering it was the very issue that absorbed them in accounting for recent attempts at interpreting both Beethoven's Ninth and McClary's writing on the symphony.

As a conclusion to this survey of various scholars' uses of Rich's poem, we might begin to turn our ears toward this noise, returning to its text in order to confront the possibility and the peril it engenders. This return to the poem may uncomfortably recall the familiar injunction of feminist musicology's detractors to limit criticism to the text itself. But this resemblance is, however, only superficial: What follows is not an attempt to uncover what the poem's text truly means-a meaning earlier writers' biases had obscured or overlooked-but to contextualize the citations of the poem catalogued above. Indeed, it presents less a reading of Rich's text than a tentative, exploratory study of its potential for signification. Motivated by a desire to better understand the poem's relation to musicology, it asks what makes writers' uses of the poem possible, and what insights the poem might inspire should we make use of it differently, taking it as a starting point for, rather than a supplement to, a line of thought. In fact, a closer look at Rich's text can suggest the necessity, not the insufficiency, of the above critics' expediency.

The poem's title alone poses many questions: It seems to downplay Beethoven and emphasize his symphony by relegating its composer to the interior of the phrase. What is more, there is no indication of who is doing the 


\section{Current Musicology}

understanding or when it took place. It could be Rich in this poem or even Burgess or Kubrick, whose roughly contemporary hearings of the Ninth could still justify the "at last" (itself a loaded phrase, suggesting the emergence of some long-awaited force that might begin to right the many wrongs of a troubled reception history). The close of the title is the most difficult part to parse. Are we to understand the symphony as equivalent to a sexual message or as similar to one? Can it be a sexual message while it is also something else? Is this sexual message one of many possible (sexual) messages? Is it a message about sex, or a message whose symphonic modality is sex itself?

Rich then introduces us to a nameless man: perhaps Beethoven, perhaps a personification of the symphony, or even of some musical-metaphoric agent within the symphony. The man feels terror, not fear, from which some critics might extract a reference to the sublime. But could the fact that he is terrified of being impotent (helpless) or infertile (unproductive) instead suggest that his terror is directed at sublimity itself? We learn that the man is trying (though with unknown success) to send a message, which may or may not be the sexual message of the title. The interpretations multiply from this point: Is he unsuccessful in his communication because the pain of the climacteric (of his mid-life andropause) causes him to howl? Is his (sexual) message so animal that only howling can transmit it? Is he experiencing the climacteric or is his music climacteric? (Lack of punctuation makes this ambiguity especially prominent.) Does he howl from within the music or overtop it? Or-in one particularly subversive reading - is he trying to tell something that is howling apart from the climacteric music? By this interpretation, the man might be trying to analyze the music just as Rich and McClary are.

Is it the "man" of the first line "yelling at Joy from the tunnel of the ego" or is it the "isolated soul," or even the music? The parallelism between this line and "howling from the climacteric / music" suggests a change in perspective that heightens this confusion. Howling gains a linguistic quality, becoming "yelling," and the "tunnel of the ego" comes across as more directed and conscious than suffering at the hands of the climacteric. "Music without the ghost / of another person in it" is an even more puzzling line: Is this to say that the music is haunted by one ghost already? Would it be the man's or that of the isolated soul-or that of Beethoven? Perhaps it indicates the entrance of a new agent, or the ghost of a canon or tradition.

As these questions pile up, the poem hits a point of symmetry, and Rich echoes several constructions from the first half of the poem in reverse order. Note the symmetrical placements of the lines describing music, the comparison 
of "howling from" and "yelling [...] from," and the difference between "a man trying to tell something" (and possibly failing) and "music / trying to tell something" while the man hopes it fails. The poem's symmetry creates a hall of mirrors effect and clouds the text further as readers try to connect referents from the first and second halves. Is the man trying to deliver the sexual message or is the music? How can Joy be the recipient of his angry yelling and simultaneously the violent weapon he uses to ensure the music's silence? If silence is the goal, why is he flogging Joy "where everything is silence"? How can this place be silent if there is so much howling, yelling, and flogging?

On closer inspection, Rich's poem, with its provocative topic and striking language, is unclear in its meaning. Its ambiguity is the product of a lack of punctuation, confusing syntax, and its strange juxtaposition of images and descriptions. Words pass by like the wind, leaving impressions but fleeting comprehension. And in the end the poem comes across more as something felt than "Understood At Last." It is a rather familiar feeling to those acquainted with Rich's larger body of work, which is uniquely attuned to the prospect of violence, the power of the visceral, and the potential of the voice. Recognizing the oppressive structures that impose and enforce societal norms (including artistic canons), Rich often turns to descriptions of the body in her poetry to account for these violent forces by depicting the place where their effects are felt. In her hands, such descriptions not only vividly portray the physical impact of this violence but also reflect something of its psychic repercussions, demonstrating that violence both leaves its mark on the physical body and isolates individuals as well. Rich's "Beethoven" poem is exemplary in this regard, portraying the isolating effects of violence not only in the events it describes but also in its description of these events: Its textual noise simulates the overwhelming experience of what Rich hears as the violence of Beethoven's work, an experience which, understandably, she cannot easily communicate.

And yet just as Rich's poem demonstrates the limiting effects of social norms and the isolating effects of the violence through which these norms are maintained, it also strives-with some success-to transcend that limitation and isolation in communicating with its reader. Her work leverages the power of noise not simply to represent the experience of violence, nor simply to demonstrate the difficulty of representing that experience to others, but to convey to the reader how, through careful and creative listening, it is possible to address that violence and pose a challenge to the structures which enact it. And by requiring this same attention of her audience, Rich suggests how we might accomplish this task ourselves. Rich's noise, then, is not simply a symptom of the 


\section{Current Musicology}

outspoken nature of her activism or a sign of her poem's failure to articulate a particular Message, but comprises something tactical. The centrality of this strategy to Rich's poetry demands focused and intentional reading from her audience, a deliberate engagement with the text that acknowledges not only the difficulty of her subject, but also that of her writing.

\section{Inconclusion}

Both Rich's perspective on the oppressive forces that enact and maintain social norms and her clever treatment of language render her poetry distinctive, undoubtedly. But in its revolutionary noise, manipulative syntax, self-reflection, and terrifying impact, does her work not recall a common characterization of Beethoven's Ninth? Just as supporters of Rich's writing recognize her confrontational, experimental work as a means of coming to terms with violence, the late Maynard Solomon (1986) identified a progressive, disruptive energy propelling "a search for order" in the Ninth. Just as Rich insistently strings together a series of ambiguously related phrases in her "Beethoven" poem, McClary (1987 and 1991) describes a similar insistence behind the horrifying harmonic syntax of Beethoven's symphony. And just as we have considered the difficulty of Rich's poem to be a product of its textual noise, Fink (2004, 142) describes the "sublimity" of the Ninth in terms of a similar "noise". I mention this not to equate the two works absolutely (nor, certainly, to justify one by the other) but rather to suggest in passing how the preceding citations of the poem, stressing secondhand its opposition to the symphony, risk overlooking their potential (and potentially strategic) similarities-as well as to return to the question of the role of Rich's poem in musicology. For this resemblance between Beethoven's Ninth and Rich's "Beethoven" poem gets at the central issue surrounding the latter's reception.

If Rich's poem teaches us about the difficulty of interpretation, its lesson is not an unfamiliar one. This same difficulty was keenly felt in the heated debates over feminist interpretations of the Ninth Symphony's own noise (and in discussions of the rich language of McClary's essay). But while Beethoven's work-via McClary's analysis-inspired lively discussion on this topic, sparking a debate over the ethics of interpretation, Rich's poem never featured in these discussions as a difficult, noisy text. And so, even if the complexity of Rich's work suggests an explanation for why musicologists have engaged with the text so cursorily, the question remains why this treatment of the poem persisted despite the concerns of the very musicologists who invoke the poem in debates over the 
means and ends of interpretation. And perhaps more crucially, the question remains what scholars today are to make of this.

Reviewing musicologists' citations of Rich's "Beethoven" poem, it would seem that the concerns that motivated these critics to turn to the poem in the first place remain far from resolved - and not just because Rich's account of the symphony, like McClary's after her, is still widely perceived as radical or because the ethics of their musical hermeneutics remains a topic of lingering debate in contemporary musicology. It is also because scholars' apparent inattention to the textual noise of Rich's poem amid a debate over the ethics of interpretation unsettles the lessons that this fabled debate is supposed to have taught us about music criticism: First, that the significance of a text is a product neither of the text itself nor of the analyst's invention alone, but instead emerges from the interaction of these potentials. And second, that this contingency demands the critic take special care not only in interpreting a text, but also in relaying their experience of it to a reader. That critics citing the "Beethoven" poem often appear to defer to Rich's work as a text able to speak for itself or as a provocation for a reader's speculation (and, in either case, appear to downplay their role in representing the complexity of the text to their audience) would seem inconsistent with these teachings. ${ }^{10}$ This presents a challenge for scholars confronting these writings today, which risk perpetuating the very myths (of the text's autonomy, or else of its meaning as an arbitrary product of a reader's will) their authors would like to dispel.

And yet this inconsistency cannot be simply resolved by insisting that musicologists could have engaged with Rich's poem more thoroughly or more carefully. For one, it is not a matter of assigning fault to individual authors. Not only can no one writer be blamed for this systematic treatment of the poem, but also many critics have perfect reason to make use of Rich's verse the way they do-whether because the poem is peripheral to their argument or perhaps because their deferrals to its suggestive language are meant to encourage the same kind of meta-textual reflection in their readers as Rich's poem does. ${ }^{11}$ Beyond this however, musicologists' treatment of the "Beethoven" poem ought not be singled out as some egregious oversight because, in the end, their passing references to Rich's verse represent an inevitability of criticism, the incompleteness of any encounter with the text. However intently these writers might focus on Rich's poem, their engagement with it could never have adequately captured its noise: there would always remain some unexplored significance. (In fact, insofar as this apparent neglect of Rich's verse itself reveals this unexplored significance, even if unintentionally, their treatment of the poem 


\section{Current Musicology}

in the end succeeds in relating the text to their central lesson about the contingency of reading, demonstrating the very point to which these authors would, in this context at least, seem blind.)

If further reflection on Rich's verse seems warranted then-to reacquaint ourselves with the poet's testimony and with the myth of Beethoven's Ninth, and still more vitally to reconsider the significance of this mythic moment in the history of our discipline-it is not because our treatment of her "Beethoven" poem requires correction per se, but because it reminds us that the possibilities and perils of interpretation can never be entirely resolved, only negotiated. Accordingly, this confrontation with the fraught reception history of Rich's poem ought not be taken as a solution to a disciplinary problem, but rather as a renewal of a familiar call to take care in our reflections on Beethoven, on McClary, and on the exchange of words her texts inspired. For Rich's poem has inspired and can continue to inspire musicologists to reflect on how we recognize and respond to a text's calls for interpretation, how we negotiate what a text's noise promises and imperils in order to understand its significance, and how we convey this noise and significance to our readers. In sum, her verse teaches us to consider how our interpretive work and our struggles to represent that work to our readers contribute to disciplinary mythologies, such as that which has grown up around Rich's poem, often in unexpected ways. Taking this lesson to heart will benefit us not just during this Beethoven Year, but in all of our efforts to represent this history, in all its intricacy, to new generations of scholars.

For now, however, we might pause to recognize that the poem is complex and to acknowledge what that complexity means-that Rich's verse has presented, and will continue to present, seemingly endless opportunities to be read. Granted, this may seem an inadequate expression of the work's value. And yet if this complexity constitutes the very origin of its value and of its usefulness to musicology, perhaps simply admitting this might suffice as a necessary first step toward both a more nuanced understanding of this value and a greater appreciation of the unsung roles Rich and her poem have played in our writing. Perhaps now, having waded toward (if not quite yet dived into) the wreck the poet's text pronounces, musicology can find its way back to this consequential poem to consider it anew in all its riches. 


\section{Acknowledgements}

An early version of this essay was presented at the fifteenth biennial conference on Feminist Theory and Music (FT\&M 15), held June 6-9, 2019 in Boston, Massachusetts. Since then it has benefitted from the generous feedback of several readers, including its anonymous reviewers. Among these, special thanks are due, for her keen comments and encouragement, to Bonnie Gordon, to whom this paper is admiringly dedicated.

Notes

${ }^{1}$ Accordingly, this essay is not concerned with re-litigating the validity of the claims it rehearses or with reconstructing the original contexts in which they were made. Rather, it considers what individual musicologists' treatment of Rich's poem suggests about its significance. It does not seek to recover some lost knowledge (the true message of the poem or of McClary's essay, or else the broader "truth" or "falsehood" of feminist criticism), but to reflect on how this mythic moment in musicology appears to scholars today and what we are to make of that appearance.

${ }^{2}$ Here and below, I capitalize the word Joy when speaking of it in the context of Rich's poem. In doing so I hope to convey something of the spirit with which Rich herself capitalizes the word (one of the notably few capitalized words in her poem), including its ambivalent reference both to the object of Schiller's Ode and to a woman's name.

3 See Solie 1991, 407. For more on the theory of compulsory heterosexuality, consult Rich 1980. Similarly to Solie, Paula Higgins perhaps alludes to Rich in a discussion of McClary's book through her description of Beethoven as "androgyne", a term which appears with some frequency in Rich's writing, including in Diving into the Wreck (Higgins 1993, 185).

${ }^{4}$ See Treitler 1992, especially 41-42. Respect for Rich's poem among McClary's critics amounts to something of a recurring theme: In a letter to the editor of the Minnesota Composer's Forum Newsletter published two months after McClary's essay, Jim Philips, condemning McClary's "ridicule" of the Classical canon, notes by contrast that he finds Rich's poem admirable, observant, and candid by comparison, even if he does not agree with it (Philips 1987, n.p.). Though note that for all Treitler's apparent respect for Rich's poetry, he does mistitle her work in his paper, omitting Beethoven's name.

${ }^{5}$ What is more (and again like Treitler), Smart mistitles Rich's poem, omitting "of Beethoven."

${ }^{6}$ Cusick 1999, 488. Cusick seems to deny that McClary wrote things in Feminine Endings that she did write (or at least suggest) in the original "Beanstalk" essay (see Fink 2004, 109 110).

7 Levy 2003, 17; Lockwood 2003, 420. Lockwood does name Rich in an endnote. In Harvey Sachs's monograph on the Ninth, the author quotes from Lockwood's work, restoring Rich's name, though he offers no additional comment on either's writings (2010, 131-32).

${ }^{8}$ Broyles fails to mention a still more puzzling detail that further complicates the poem's history: in 1972, the year of the Beethoven poem, Rich met with Anthony Burgess, who sublet her New York apartment and described its infestation by cockroaches in an article in the New York Times. Their acquaintance soured, and Burgess would later pen a thinly veiled caricature of Rich and her apartment in a novel titled The Clockwork Testament. Rich's 


\section{Current Musicology}

response to this work is unknown. For a more detailed history of this encounter, see Biswell 2012.

9 Passing references to Rich's poem can be found in writings on a variety of musical topics, from the soundtracks to Kubrick's films to the origins of melodrama: A study of A Clockwork Orange asks readers to consider the poem's message given only its title, its author's name, and its opening line (Gengaro 2013, 124). While an essay on Fidelio, describing the poem's "sexual message" as the "impotent and infertile cry of a man wrapped up in himself, hating women, loving men as he loves himself," includes none of its actual text (Goldberg 2016, 14).

${ }^{10}$ It also unsettles the neat categories into which history has sorted the partisans in this debate: Feminist writers advocating for context and interpretive nuance defer to the poem to speak for itself, while the textualist Treitler suggests the subtlety required in interpretation.

${ }^{11}$ It is possible to read Cusick's comments about Rich's poem in this light, for example. Though as we have already seen, in appropriating the poem's noise in this way, Cusick runs the risk of suggesting to her readers that the significance of Rich's work is so obvious that it need only be quoted directly from Rich's verse (obvious, at least, to those acquainted with its particular "intellectual context"-another way of limiting its potential for signification). It would seem, then, that critics who wish to represent Rich's text in all its complexity to their reader ought not shy away from the difficulty of their encounter with the poem, but rather dramatize it in their own writing, so as to acknowledge the limitation of their perspective on the poem and of their ability to communicate their experience of the text to their audience. This style of writing is familiar to both the feminist and queer critical traditions to which Rich belonged, discourses concerned with how subjects whose significance are discounted are able to make meaning from their experience of difference. (For more on this hermeneutic strategy, its means and ends, approached from a specifically queer perspective, see Shiflett 2020.) But beyond the personal and historical relevance of this style of criticism to Rich the lesbian and Rich the feminist/queer critic, it fits Rich's writing so well because her texts themselves demand it, engaging their reader as an individual whose interpretive faculty is shaped by their difference. Certainly, this is true of the "Beethoven" poem, which not only dramatizes Rich's encounter with the Ninth, but also confronts the reader with the task of understanding Rich's perspective on the symphony-and of reconciling their thoughts with her own.

\section{References}

Bennett, Paula. 1986. My Life a Loaded Gun. Boston: Beacon Press.

Biswell, Andrew. 2012. "Adrienne Rich, Anthony Burgess and the cockroaches" News and Blog Posts, The International Anthony Burgess Foundation:

https://www.anthonyburgess.org/blog-posts/adrienne-rich-anthony-burgess-andthe-cockroaches-by-andrew-biswell/.

Broyles, Michael. 2011. Beethoven in America. Bloomington: Indiana University Press.

Cusick, Suzanne G. 1999. “Gender, Musicology, and Feminism.” In Rethinking Music, edited by Nicholas Cook and Mark Everist. Oxford: Oxford University Press, 471-98.

DeNora, Tia. 1997. "Music and Erotic Agency: Sonic Resources and Social-Sexual Action" Body and Society 3: 43-65. 
Fink, Robert. 2004. "Beethoven Antihero: Sex, Violence, and the Aesthetics of Failure, or Listening to the Ninth Symphony as Postmodern Sublime." In Beyond Structural Listening? Postmodern Modes of Hearing, edited by Andrew Dell'Antonio. Berkeley, University of California Press, 109-153.

Gengaro, Christine. 2013. Listening to Stanley Kubrick: The Music in his Films. Lanham: Scarecrow Press.

Goldberg, Jonathan. 2016. Melodrama: An Aesthetics of Impossibility. Durham: Duke University Press.

Higgins, Paula. 1993. "Women in Music, Feminist Criticism, and Guerrilla Musicology: Reflections on Recent Polemics" Nineteenth-Century Music 17: 174-192.

Hudgins, Andrew. 1981. “The Burn Has Settled In’: A Reading of Adrienne Rich's Diving into the Wreck" The Texas Review 2: 49-65.

Keyes, Claire. 1986. The Aesthetics of Power: The Poetry of Adrienne Rich. Athens: University of Georgia Press.

Kreiling, Jean L. 2012. “'Yelling at Joy': Poetic Responses to Beethoven's Ninth Symphony" The Beethoven Journal 27: 56-63.

Lemardeley-Cunci, Marie Christine. 1990. Adrienne Rich: Cartographies du silence. Lyon: Presses Universitaires de Lyon.

Levy, David. 2003. Beethoven: The Ninth Symphony. New Haven: Yale University Press. Lockwood, Lewis. 2003. Beethoven: The Music and the Life. New York: Norton.

Markey, Janice. 1985. A New Tradition? The Poetry of Sylvia Plath, Anne Sexton and Adrienne Rich. New York: Peter Lang.

McClary, Susan. 1987. “Getting Down Off the Beanstalk: The Presence of a Woman's Voice in Janika Vandervelde's Genesis II" Minnesota Composers Forum Newsletter (January), n.p. 1991. Feminine Endings: Music, Gender, and Sexuality. Minneapolis: University of Minnesota Press.

Pasler, Jann. 1992. “Some Thoughts on Susan McClary's Feminine Endings" Perspectives of New Music 30: 202-205.

Philips, Jim. 1987. “Re: Susan McClary's Beanstalk” Minnesota Composers Forum Newsletter (March), n.p.

Rich, Adrienne 1973. "The Ninth Symphony of Beethoven Understood at Last as a Sexual Message." In Diving into the Wreck. New York: Norton, 43. 1980. "Compulsory Heterosexuality and Lesbian Existence" Signs: Journal of Women in Culture and Society 5: 631-60.

Sachs, Harvey. 2010. The Ninth: Beethoven and the World in 1824. New York: Random House.

Shiflett, Campbell. 2020. “'Au Fond d'un Placard’: Allusion, Narrative, and Queer Experience in Poulenc's Ier Nocturne” The Journal of Musicology 37: 197-230.

Smart, Mary Ann. 1994. "Review of Musicology and Difference: Gender and Sexuality in Music Scholarship, edited by Ruth A. Solie" Journal of the American Musicological Society 47: 541-49.

Solie, Ruth A. 1991. "What do Feminists Want? A Reply to Pieter van den Toorn" The Journal of Musicology 9: 399-410. 


\section{Current Musicology}

Solomon, Maynard. 1986. "Beethoven's Ninth Symphony: A Search for Order" $19^{\text {th }}$-Century Music 10: 3-23.

Taruskin, Richard. 2009. “A Beethoven Season?” In The Danger of Music and Other AntiUtopian Essays. Berkeley: University of California Press, 71-80.

Templeton, Alice. 1994. The Dream and the Dialogue: Adrienne Rich's Feminist Poetics. Knoxville: University of Tennessee Press.

Treitler, Leo. 1992. "Gender and Other Dualities of Music History." In Musicology and Difference: Gender and Sexuality in Music Scholarship, edited by Ruth A. Solie. Berkeley: University of California Press. 23-45.

van den Toorn, Pieter. 1991. "Politics, Feminism, and Contemporary Music Theory" The Journal of Musicology 9: 275-299. 1995. Music, Politics, and the Academy. Berkeley: University of California Press. 